archives-ouvertes

\title{
Resistance against barley leaf rust (Puccinia hordei) in West-European spring barley germplasm
}

\author{
Rients Niks, Ursula Walther, Heidi Jaiser, Fernando Martinez, Diego Rubiales
}

\section{To cite this version:}

Rients Niks, Ursula Walther, Heidi Jaiser, Fernando Martinez, Diego Rubiales. Resistance against barley leaf rust (Puccinia hordei) in West-European spring barley germplasm. Agronomie, EDP Sciences, 2000, 20 (7), pp.769-782. <10.1051/agro:2000174>. <hal-00886084>

\section{HAL Id: hal-00886084 \\ https://hal.archives-ouvertes.fr/hal-00886084}

Submitted on 1 Jan 2000

HAL is a multi-disciplinary open access archive for the deposit and dissemination of scientific research documents, whether they are published or not. The documents may come from teaching and research institutions in France or abroad, or from public or private research centers.
L'archive ouverte pluridisciplinaire HAL, est destinée au dépôt et à la diffusion de documents scientifiques de niveau recherche, publiés ou non, émanant des établissements d'enseignement et de recherche français ou étrangers, des laboratoires publics ou privés. 


\title{
Resistance against barley leaf rust (Puccinia hordei) in West-European spring barley germplasm
}

\author{
Rients E. NiKs ${ }^{\mathrm{a} *}$, Ursula WALTHER ${ }^{\mathrm{b}}$, Heidi JAISER ${ }^{\mathrm{c}}$, Fernando MARTÍNEZ $^{\mathrm{d}}$, Diego Rubiales ${ }^{\mathrm{d}}$, \\ Ole AnderSEN**, Kerstin Flath**, Paul GYMER**, Fritz HeINRICHS**, \\ Rickard JonsSON**, Lissy KunTZE**, Morten RASMUSSEN**, Edeltraut RiCHTER** \\ ${ }^{a}$ Laboratorium voor Plantenveredeling, Wageningen University, Postbus 386, 6700 AJ Wageningen, The Netherlands \\ ${ }^{\mathrm{b}}$ Bundesanstalt für Züchtungsforschung an Kulturpflanzen, Theodor Roemer-Weg 4, 4320 Aschersleben, Germany \\ ${ }^{\mathrm{c}}$ Pajbjergfonden, Gersdorffslundvej 1, Hou, 8300 Odder, Denmark \\ ${ }^{\mathrm{d}}$ Instituto Agricultura Sostenible, CSIC, Apdo 4084, 14080 Córdoba, Spain
}

(Received 28 April 2000; revised 9 July 2000; accepted 15 August 2000)

\begin{abstract}
The level and type of resistance against leaf rust (Puccinia hordei) was determined in modern spring barley germplasm. In field trials all over Europe most accessions were in some locations and years significantly less infected than the moderately resistant reference 'Grit'. Differentiating $P$. hordei isolates indicated that most accessions carried hypersensitivity $(R p h)$ genes. A virulence survey indicated that among the known resistance genes, only $R p h 7$ is still fully effective in Europe. Some accessions carried undetermined hypersensitivity resistance gene(s) that were effective to all isolates tested. The level of non-hypersensitivity or partial resistance was assessed from the latency period of the fungus and the percentage of early aborted infection units not associated with plant cell necrosis. These parameters indicated that several accessions had a level of partial resistance higher than that of the highly partially resistant 'Vada'. We concluded that barley breeders have achieved very high levels of partial resistance against $P$. hordei in spring barley germplasm.
\end{abstract}

\section{barley / leaf rust / partial resistance / virulence / hypersensitivity}

Résumé - Résistance à la rouille brune (Puccinia hordei) du germplasme d'orge de printemps d'Europe de l'ouest. Le niveau et le type de résistance contre la rouille brune (Puccinia hordei) ont été déterminé chez le germplasme d'orge de printemps. Dans des champs expérimentaux présents dans l'Europe entière, la plupart des accessions ont été pour certains sites et années, moins infectées comparé à la référence 'Grit' qui est modérément résistante. Des isolats de $P$. hordei différenciés ont indiqué que la plupart des accessions contenaient les gènes d'hypersensitivité $R p h$. Un test de virulence a indiqué que des gènes $R p h$ connus, seul $R p h 7$ est encore complètement efficace en Europe. Certaines

Communicated by Hanne Østergård (Roskilde, Denmark)

* Correspondence and reprints rients.niks@pv.dpw.wau.nl

** Affiliations are in Appendix 
accessions contenaient des gènes d'hypersensitivité indéterminés qui se sont avérés efficaces contre tous les isolats testés. Le niveau de non-hypersensitivité ou résistance partielle a été évalué en fonction de la période latente du champignon et du pourcentage des parties infectées après avortement hâtif non associés à la nécrose des cellules végétales. Ces paramètres ont indiqué que plusieurs accessions présentent un niveau de résistance partielle plus élevé que celui de la référence avec résistance partielle, 'Vada'. Nous pouvons donc conclure que les sélectionneurs d'orge ont atteint des très hauts niveaux de résistance partielle contre $P$. hordei chez le germplasme de l'orge de printemps.

orge / rouille brune / résistance partielle / virulence / hypersensitivité

\section{Introduction}

Barley leaf rust, caused by Puccinia hordei Otth, occurs wherever barley (Hordeum vulgare L.) is cultivated. The economic importance of the rust depends on the region in the world, and varies from year to year. In Europe, the disease is generally more important in the temperate and warmer regions, like the United Kingdom and France, and less so in the more northern parts of Europe. In 1998 and 1999, for example, leaf rust was among the most important barley pathogens in the UK (Clarkson, NIAB, Cambridge, UK, pers. comm.). Losses of about 10 to $25 \%$ have been cited for the Czech Republic [3]. It appears that the economic importance of barley leaf rust has increased in recent years $[2,4]$.

In Europe, farmers apply repeated fungicide treatments on barley to protect against fungal leaf pathogens, including barley leaf rust. There is increasing opposition to the application of pesticides in agriculture, because of the environmental and health risks.

The most obvious alternative to fungicide treatment is the use of resistant cultivars. Resistance in barley to $P$. hordei is widely available. There are two types of resistance to this pathogen: hypersensitivity resistance and non-hypersensitivity resistance [1]. The hypersensitivity resistance is governed by major genes $(R p h)$, that are race-specific [5]. This resistance is often complete, and associated with necrosis of plant cells that are attacked by the pathogen sporelings. Some of the $R p h$ genes have a delayed or rather weak effect on the pathogen. Such Rph genes confer incomplete resistance, in which the fungus forms small uredinia that are surrounded by chlorotic or necrotic plant tissue (i.e. low to intermediate infection types).

The non-hypersensitivity resistance, also called "partial resistance" [18], is not associated with plant cell necrosis. It has a typically quantitative inheritance $[13,20]$. In field trials this resistance is characterised by low levels of infection despite a compatible (high) type of infection. In monocyclic tests in the greenhouse, partially resistant barley genotypes are identified by the long latency period of the fungus and the low infection density as compared to the susceptible reference cultivars [15].

Breeding for resistance to leaf rust in barley has not received top priority in European barley programmes. However, selection against very susceptible phenotypes occurs. In several barley breeding programmes, artificial inoculations are made on breeding lines to facilitate this selection. Such procedures might result in the gradual accumulation of quantitative genes for resistance [14, 17].

Here we describe the resistance of a set of modern West-European spring barley germplasm against $P$. hordei. The accessions were tested at several locations with the objective of assessing the level and the type of their resistance. This research was complemented by a virulence survey to determine which $R p h$ genes are still effective to the pathogen in Europe, and the frequency of possible virulence factors in the $P$. hordei population. Histological and macroscopic observations were carried out in a monocyclic greenhouse test to determine the level of non-hypersensitivity resistance in the tested lines. 


\section{Materials and methods}

\subsection{Multi-location field test for resistance}

\subsubsection{Plant material, locations and experimental design}

Twenty-nine cultivars and breeding lines of spring barley were obtained from seven breeding companies or research institutes in Germany, Denmark and the Netherlands. Almost all those accessions were cultivars that had been released since 1990 , or breeding lines just about to be released. They had displayed consistently low levels of leaf rust infection in the breeders' field trials, and hence were presumed to be partially resistant. 'Alexis' was added as a susceptible reference (three times), and 'Grit' as a moderately resistant reference (four times). 'Grit' was used as reference, since it had shown a moderate and stable level of resistance during 12 years of experiments between 1981 and 1995 [29]. The set also contained the lines L94 (extremely susceptible), 116-5 and 'Vada' (high level of partial resistance) and 175-16 (extreme level of partial resistance, [19]).

In 1998, the set was tested at eight locations in four countries: Aschersleben, Hadmersleben and Langenstein (Germany); Abed, Sejet and Pajbjerg (Denmark); Sandon (UK); and Wageningen (the Netherlands). In 1999 the set was planted at the same locations, but instead of Wageningen, Landskrona (Sweden) and Radzikow (Poland) were included. Four of the lines tested in 1998 were replaced by new accessions in the 1999 set. This paper reports only on the accessions that were included in both years' trials.

The planting and leaf rust evaluations were carried out according to the RESI procedure [7]. At each testing site, the set was sown in three or four complete randomised blocks. The accessions were planted as microplots (double rows), or as single rows. Each plant row was $90-120 \mathrm{~cm}$ long with an inter-row spacing of about $25 \mathrm{~cm}$. For each accession about 50 seeds were available per replication.

A spreader row, consisting of a mixture of very susceptible barley lines or cultivars, was sown in the alleyways, perpendicular to the test entries, or alternating with them as microplots. At some locations, the leaf rust epidemics were initiated by artificial inoculation of the spreader rows, whereas in other locations, the epidemic occurred spontaneously.

\subsubsection{Evaluation of infection levels}

Where possible, the trials were evaluated three times during the growing season starting at the tillering stage (growth stages 21-23, [31]). The assessed parameter was the average percentage of leaf area covered by the rust uredinia. A disease severity scale was provided to the evaluators at each location in order to reduce bias between locations and evaluators.

Data analysis was performed with the SASapplication RESI [7]. The mean disease severity per accession per location per year was calculated as a mean of scores and replications.

\subsection{Evaluation for race-specific hypersensitivity resistance}

At the Bundesanstalt für Züchtungsforschung und Kulturpflanzen, Aschersleben, Germany, seedlings of the accessions were inoculated with six barley leaf rust isolates, representing different virulence patterns (Tab. I). In the 1999 test the isolate 16-3 was replaced by 23 . At the Laboratory of Plant Breeding in Wageningen, the seedlings were inoculated at the seedling stage with isolate 24 (Tab. I). Infection types were recorded to aid in the postulation of $R p h$ genes in the accessions.

\subsection{Virulence surveys}

Samples of the $P$. hordei population were collected in 1998 in seven European countries: Germany (5 locations), France (4), the United Kingdom (3), Switzerland (1), Austria (1), Denmark (1) and Belgium (1). The sampling was carried out in 1998 by Felsenstein, Munich, Germany, by use of mobile spore traps [25]. Most of the German isolates had been provided by various breeding stations. Spores from single uredinia 
Table I. Infection types (on 0-4 scale) ${ }^{1}$ of isolates of Puccinia hordei that differentiate between the various Rph resistance genes in barley.

\begin{tabular}{|c|c|c|c|c|c|c|c|c|c|}
\hline \multirow[t]{2}{*}{ Cultivar } & \multirow[t]{2}{*}{ Rph-gene } & \multicolumn{8}{|c|}{ Isolates } \\
\hline & & $54-3$ & $16-3$ & 23 & I 80 & $8-2$ & $8-1$ & $30-1+4280$ & 24 \\
\hline 'Sudan’' & Rphl & $0-2$ & $2^{-}$ & 4 & 4 & 4 & 4 & 4 & 4 \\
\hline 'Peruvian' & Rph2 & 4 & 3 & 4 & 4 & $2-$ & $2-$ & 4 & 4 \\
\hline Hor679-3 & Rph3 & 0 & 0 & 0 & 3 & 3 & 0 & 0 & 0 \\
\hline 'Gold' & Rph4 & 4 & 4 & 4 & 4 & 4 & 4 & 4 & 4 \\
\hline ‘Quinn’ & $R p h 2+R p h 5$ & 4 & $2^{-}$ & 4 & 0 & 0 & 0 & 0 & 0 \\
\hline 'Bolivia' & $R p h 2+R p h 6$ & 4 & 4 & 4 & 3 & $0-2$ & $0-2$ & 3 & 4 \\
\hline Hor4279 & $\operatorname{Rph} 7$ & 0 & 0 & 0 & 0 & 0 & 0 & 0 & 0 \\
\hline Egypt 4 & $\operatorname{Rph} 8$ & 4 & 3 & 4 & 4 & 4 & 4 & 4 & 4 \\
\hline Hor2596 & $R p h 9$ & 0 & 0 & 0 & 3 & 0 & 0 & 4 & 0 \\
\hline Hor500-1 & & 0 & 0 & 0 & 3 & 4 & 4 & 4 & n.t. \\
\hline Hor1132 sel. & & 3 & 0 & 0 & 0 & 0 & 0 & 0 & n.t. \\
\hline ‘Trumpf' & Rph12 & 0 & 0 & 0 & 3 & 0 & 0 & 4 & 4 \\
\hline 'Lada' & Rph12 & 0 & 0 & 0 & 3 & 0 & 0 & 4 & 4 \\
\hline
\end{tabular}

${ }^{1}$ infection types 3 and 4 indicate virulence; 0 to 2 indicate avirulence. n.t.: not tested.

Table II. Percentage of mono-uredinia-derived isolates of the barley leaf rust fungus (Puccinia hordei), collected in 1998 , that carry virulence to resistance factors in 15 differential barley lines.

\begin{tabular}{|c|c|c|c|c|c|c|c|c|}
\hline \multirow[t]{2}{*}{ Barley line } & \multirow{2}{*}{$\begin{array}{c}\text { Resistance } \\
\text { gene }(\mathrm{s})\end{array}$} & \multicolumn{7}{|c|}{ Country of origin and number of isolates tested } \\
\hline & & $\begin{array}{c}\text { Germany } \\
98\end{array}$ & $\begin{array}{c}\text { France }^{2} \\
82\end{array}$ & $\begin{array}{c}\mathrm{UK}^{3} \\
72\end{array}$ & $\begin{array}{c}\text { Switzerland } \\
17\end{array}$ & $\begin{array}{c}\text { Austria } \\
33\end{array}$ & $\begin{array}{c}\text { Danmark } \\
17\end{array}$ & $\begin{array}{c}\text { Belgium } \\
22\end{array}$ \\
\hline ‘Sudan’ & Rphl & 100 & 100 & 100 & 100 & 100 & 100 & 100 \\
\hline 'Peruvian' & Rph2 & 100 & 100 & 100 & 100 & 100 & 100 & 100 \\
\hline RikaxF1 & Rph3 & 58 & 59 & 21 & 35 & 30 & 71 & 55 \\
\hline 'Estate' & Rph3 & 69 & 58 & 28 & 65 & 70 & 71 & 68 \\
\hline Hor679-3 & Rph3 & 75 & 84 & 40 & 71 & 85 & 88 & 77 \\
\hline 'Gold' & Rph4 & 100 & 100 & 100 & 100 & 100 & 100 & 100 \\
\hline ‘Quinn’ & $R p h 2+R p h 5$ & 20 & 50 & 83 & 71 & 21 & 35 & 50 \\
\hline 'Bolivia' & $R p h 2+R p h 6$ & 100 & 100 & 100 & 100 & 100 & 100 & 100 \\
\hline 'Cebada Capa' & Rph7 & 0 & 0 & 0 & 0 & 0 & 0 & 0 \\
\hline Egypt 4 & Rph 8 & 98 & 95 & 97 & 100 & 100 & 100 & 86 \\
\hline Hor 2596 & Rph9 & 100 & 100 & 100 & 100 & 100 & 100 & 100 \\
\hline Hor500-1 & & 90 & 51 & 34 & 53 & 91 & 71 & 86 \\
\hline Hor1132 sel. & & 3 & 8 & 3 & 12 & 9 & 0 & 5 \\
\hline ‘Trumpf' & Rph12 & 97 & 100 & 100 & 100 & 100 & 100 & 100 \\
\hline 'Lada' & Rph12 & 98 & 100 & 100 & 100 & 100 & 100 & 100 \\
\hline
\end{tabular}

${ }^{1}$ Collected around Hamburg, Magdeburg, Hannover, Leipzig and Karlsruhe.

${ }^{2}$ Collected around Lille, Paris, Toulouse, Bourge.

${ }^{3}$ Collected around Harrogate, Cambridge, Edinburgh. 
were applied to seedling leaves of a susceptible cultivar to produce mono-uredinia-derived isolates.

A total of 341 of such isolates were applied to seedlings of 15 barley lines and cultivars to determine the virulence frequencies in the $P$. hordei populations. Most of these 15 barley accessions (Tab. II) belong to the regular differential series for barley leaf rust $[1,2,26,28]$. Three accessions with $R p h 3$ were included. Hor679-3 probably only carries Rph3. 'Estate' has been reported to differ from Hor679-3 by one and Rika $\times$ F1 by two additional resistance genes [28]. Similar samplings and virulence surveys had been carried out in other years and other locations in the framework of the present study. The results of those surveys served as back-up for the 1998 results.

\subsection{Evaluation of the level of non-hypersensitivity resistance}

The set of barley lines was grown in greenhouse compartments at the Laboratory of Plant Breeding, Wageningen, to quantify the level of non-hypersensitivity resistance in each accession. The set was sown in two series for seedling assessments and in four series for adult plant assessments. About 11 days after sowing, the first leaves were fixed in a horizontal position and inoculated in a settling tower. About four seedlings per accession were available for inoculation per series. Each box received $4 \mathrm{mg}$ inoculum, which amounts to about 200 spores per $\mathrm{cm}^{2}$. The procedure and conditions were as described by Niks and Rubiales [10].

For the adult plant evaluation, three plants were raised per accession per series. When the plants had developed about six or seven leaves, the upper surface of the uppermost fully expanded leaf (one per plant) was inoculated by dusting with inoculum. Isolate 24 of $P$. horde $i$ was used for both the seedling and the adult plant tests.

After five days, three inoculated leaves of each accession were sampled for microscopic observations. A central segment of each leaf was cut, fixed in lactophenol-ethanol, and stained with Uvitex for fluorescence microscopy $[9,24]$. For each sample, 100 infection units were inspected for their stage of development and whether they were associated with autofluorescent plant cells, indicating plant cell necrosis. The percentage of early aborted infection units not associated with plant cell necrosis was determined. Early aborted infection units have no more than six haustorial mother cells [8].

For each accession, the infection type, on a 0-9 scale, was recorded [6]. These observations were carried out on inoculated leaves that had not been sampled and/or on the leaf stubs that remained after having sampled the leaf for microscopy. On the seedling leaves, the latency period of the rust also was determined [11].

\section{Results}

\subsection{Resistance levels in spring barley accessions}

At three locations in 1998 and five locations in 1999, the level of infection was too low to allow for a rust severity rating. Moreover, in some instances, only one or two of the three proposed evaluations were made before crop maturation. At those locations, the number of uredinia per three tillers per microplot were counted (Wageningen, 1998), or a semi-quantitative rating on a 1-9 or 0-10 scale was performed (Langenstein, Abed, both years; Landskrona, 1999). At Sejet (1999) and Radzikow (1999), the level of infection was negligible, and no data were collected. At five (1998) and four (1999) locations, the level of infection was sufficient to collect data that could be considered reliable and discriminatory among the accessions (Fig. 1). In both years Hadm.18091-96 was the most resistant accession, and L94 the most susceptible.

The mean disease severity values differed substantially across the locations, but the ranking of the accessions was similar, especially among the most resistant and most susceptible accessions. Between the years there were only a few striking differences. 'Cork' was less severely infected in 1999 than in 1998. This effect seems mainly due to the lower infection at Hadmersleben. 'Ria', 'Henni' and Hadm.3500-96 were relatively more 

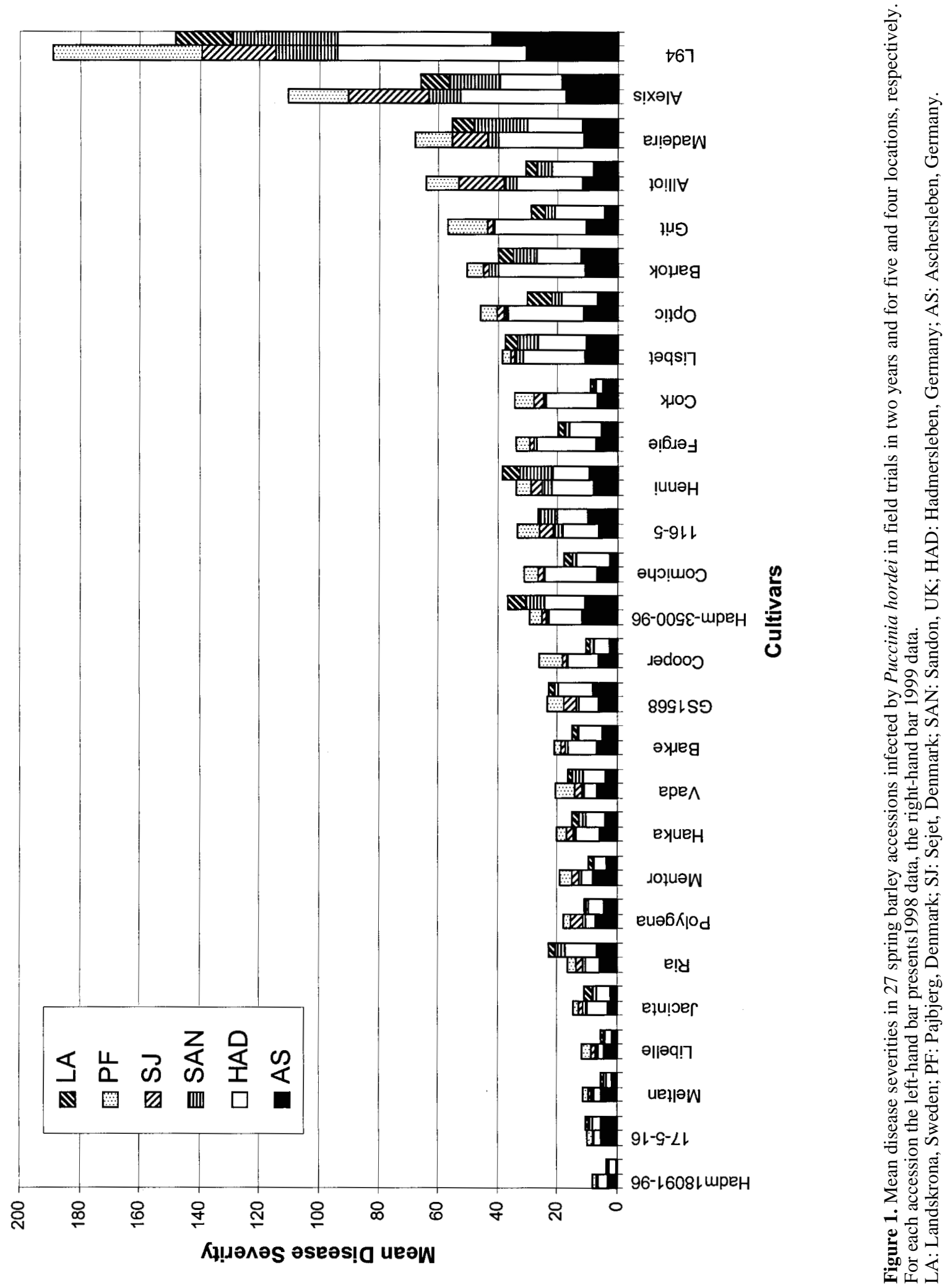
severely infected in 1999 than in 1998. With 'Ria' and 'Henni', this was likely due to higher infection at Hadmersleben. In contrast, Hadm.3500-96 had higer infection at all locations.

The test sites differed in the discrimination between levels of infection on the various accessions. In 1998, 15 accessions at Pajbjerg and 19 accessions at Hadmersleben were significantly more resistant than the reference 'Grit'. This was likely due to the relatively poor expression of resistance in 'Grit' at those locations. At Hadmersleben, where infection levels were high, 'Grit' was not significantly more resistant than the susceptible reference 'Alexis'. In the other 1998 locations, some accessions, including 'Alexis', were significantly more susceptible than 'Grit', and none significantly more resistant than 'Grit'.

Also in 1999 at Hadmersleben many accessions (21) were significantly more resistant than 'Grit'. Again, 'Grit' seemed to express its resistance poorly at this location. Also in that year, 'Grit' was not significantly different in leaf rust severity from the susceptible reference 'Alexis' at Hadmersleben. In 1999, several of the accessions were at the other locations more resistant than 'Grit' and a few were more susceptible than 'Grit'.

The number of locations in which the accessions had a mean disease severity significantly different from reference 'Grit' is presented in Table III. Also for this criterium line Hadm.18091-96 was in both years the most resistant accession, and L94 the most susceptible. 'Henni' appeared rather variable in its performance, since in both years, it had at some locations a significantly higher and in other locations a significantly lower level of infection than 'Grit'.

Seven accessions (Hadm. 18091-96, 17-5-6, 'Libelle', 'Meltan', 'Jacinta', 'Polygena' and 'Mentor') were among the ten most resistant accessions in both years. The mean disease severity (averaged over the locations) for all accessions in 1998 correlated very well with those in 1999 $(r=0.95$, significant at 0.01 level, Tab. IV $)$.

The results from the locations where low infection occurred (see above) still resulted in a similar ranking of the accessions.
We conclude that the large majority of the spring barley lines were at least as resistant as 'Grit'. With the exception of some cvs (e.g. 'Henni' and 'Cork'), the ranking of the accessions between locations and years were, in general, not very different.

\subsection{Genes for race-specific hypersensitivity resistance}

Conclusions on the presence of race specific resistance genes were based on the seedling tests with the differentiating isolates listed in Table I. The postulated resistance genes present in the accessions are presented in Table III. Nine accessions were resistant to all isolates except I 80, 30$1+4280$ and 24, suggesting the presence of Rph12. 'Barke', susceptible only to I 80 and 30-1+4280, probably carries $R p h 9$. Six accessions were only susceptible to I 80 , which may be explained by assuming the presence of both Rph 3 and $R p h 9 / R p h 12$. Isolate 24 , the only isolate that distinguishes $R p h 9$ from $R p h 12$, is avirulent to $R p h 3$ (Tab. I). This makes it impossible to determine whether the six accessions carry Rph9 or Rph 12 . The reaction pattern of 'Henni' (only resistant to 54-3, not tested against 16-3) suggested the presence of Rphl, and the reaction of Libelle (only susceptible to 8-2 and I 80) suggested the presence of Rph3.

One accession, Hadm. 3500-96, was only susceptible to isolate 24 , which cannot be explained by any of the $R p h$ gene (combinations) for which the isolates differentiated (Tab. I). That line may therefore carry an unknown $R p h$ gene. Four accessions were resistant to all isolates. One of these, 'Hanka', was derived from a parent known to carry $R p h 7$, a gene effective to all isolates used in this study (Tab. I). In the other four accessions this or other Rph gene(s) may occur.

Four accessions gave a susceptible infection type to all isolates, and therefore may not carry any of the Rph-genes to which at least one of the isolates carries avirulence. Since all isolates possess virulence for $R p h 4$ and $R p h 8$, either of those genes 
Table III. Resistance of 27 spring barley accessions to barley leaf rust, Puccinia hordei: the number of locations in which each accession was significantly less $(<)$ or significantly more $(>)$ infected than the reference 'Grit' in field tests in 1998 and 1999 (number of locations), the putative Rph-genes present in each accession, and greenhouse experiments with isolate 24 to determine the level of non-hypersensitivity resistance: the latency period relative to line L94 (relative LP), and the percentage of early aborted infection units not associated with necrosis (\% EA-N) determined in seedlings and in adult plants. The infection type (IT on a $0-9$ scale) to isolate 24 is also presented.

\begin{tabular}{|c|c|c|c|c|c|c|c|}
\hline \multirow{3}{*}{ Accession } & \multirow{2}{*}{\multicolumn{2}{|c|}{ Number of locations }} & \multirow{3}{*}{$\begin{array}{c}\text { Putative } R p h \\
\text { gene(s) present }\end{array}$} & \multicolumn{4}{|c|}{ Isolate 24} \\
\hline & & & & \multirow{2}{*}{$\mathrm{IT}^{10}$} & \multirow{2}{*}{$\begin{array}{c}\text { Relative } \mathrm{LP}^{7} \\
\text { Seedlings }\end{array}$} & \multicolumn{2}{|c|}{$\% \mathrm{EA}-\mathrm{N}^{6}$} \\
\hline & $1998^{1}$ & $1999^{2}$ & & & & Seedlings ${ }^{8}$ & Adult plants ${ }^{9}$ \\
\hline Hadm18091-96 & $2<$ & $4<$ & Rph? & 5 & - & 13 & 21 \\
\hline $17-5-16$ & $2<$ & $2<$ & - & 7 & 144 & 35 & 49 \\
\hline 'Meltan’' & $2<$ & $3<$ & $R p h 3+R p h 9 / 12$ & 3 & - & 23 & 44 \\
\hline 'Libelle' & $2<$ & $3<$ & Rph3 & 1 & - & 17 & 36 \\
\hline 'Jacinta' & $2<$ & $1<$ & Rph? & 5 & - & 44 & 56 \\
\hline 'Ria' & $2<$ & $1<$ & Rph12 & 7 & 144 & 45 & 53 \\
\hline 'Polygena' & $2<$ & $2<$ & $R p h 3+R p h 9 / 12$ & 2 & - & 13 & 26 \\
\hline 'Mentor' & $2<$ & $2<$ & $R p h 3+R p h 9 / 12$ & 1 & - & 26 & $23 *$ \\
\hline 'Hanka' & $2<$ & $1<$ & $R p h 7^{5}$ & 1 & - & 12 & 24 \\
\hline 'Vada' & $1<$ & $2<$ & - & 7 & 126 & 27 & 43 \\
\hline 'Barke' & $2<$ & $3<$ & $\operatorname{Rph} 9$ & 2 & - & $6^{*}$ & 3 \\
\hline GS1568 & $1<$ & $2<$ & $R p h 3+R p h 9 / 12$ & 1 & - & 17 & 24 \\
\hline 'Cooper' & $1<$ & $2<$ & Rph12 & 7 & 125 & 42 & 45 \\
\hline Hadm.3500-96 & $2<$ & $\mathbf{0}$ & $R p h x$ & 7 & 114 & 10 & 33 \\
\hline 'Corniche' & $2<$ & $1<$ & Rph12 & 8 & 110 & 11 & $36^{*}$ \\
\hline $116-5$ & $1<1>$ & $2<$ & - & 8 & 124 & 16 & 21 \\
\hline 'Henni' & $2<1>$ & $1<1>$ & Rhpl & 8 & 111 & 28 & 29 \\
\hline 'Fergie' & $2<$ & $1<$ & Rph12 & 8 & 114 & 9 & 15 \\
\hline 'Cork' & $1<$ & $2<$ & $R p h 3+R p h 9 / 12$ & 1 & - & 36 & 54 \\
\hline 'Lisbet' & $1<1>$ & $\mathbf{0}$ & Rph12 & 7 & 111 & 9 & 7 \\
\hline 'Optic' & 0 & $1<$ & Rph12 & 7 & 121 & 23 & 28 \\
\hline 'Bartok' & $1>$ & $1>$ & Rph12 & 7 & 127 & 22 & 44 \\
\hline 'Grit'? & 0 & $\mathbf{0}$ & Rph12 & 8 & 124 & 9 & 13 \\
\hline 'Alliot' & $2>$ & $\mathbf{0}$ & Rph? & 2 & - & 18 & 12 \\
\hline 'Madeira' & $2>$ & $2>$ & Rph12 & 7 & 105 & $2 *$ & $7 *$ \\
\hline ‘Alexis' & $4>$ & $3>$ & $R p h 3+R p h 9 / 12$ & 3 & - & 9 & 16 \\
\hline L94 & $5>$ & 4> & - & 9 & 100 & 3 & 2 \\
\hline
\end{tabular}

\footnotetext{
${ }^{1}$ Total number of locations: 5 .

${ }^{2}$ Total number of locations: 4.

3 'Grit' was included as accession, and tested against three plots per replication in which 'Grit' served as reference. effective to all differentiating isolates except isolate 24 .

${ }^{5}$ as $R p h$ ?, but $R p h 7$ gene presumed because of ancestry.

${ }^{6}$ Figures marked by $*$ are based on only one replication.

7 -: not measured because of low infection type.

${ }^{8}$ Based on two replications, three leaf segments per replication, 100 infection units per leaf segment.

${ }^{9}$ Based on four replications, three leaf segments per replication, 100 infection units per leaf segment.

${ }^{10}$ Based on the 0-9 scale of McNeal et al. [6]. For virulence spectrum of this isolate, see Table I.
}

4 -: no evidence for any $R p h$-gene; $R p h$ ?: unknown $R p h$ gene(s) effective to all differentiating isolates; $R p h x$ : unknown $R p h$ gene(s) 
Table IV. Pearson's coefficient of correlation ${ }^{\dagger}$ between Mean Disease Severity (MDS) in 1998 (over 5 locations) and 1999 (over 4 locations), relative latency period in seedling stage (RLP-seedl), early abortion without necrosis in seedling stage (EA-N-seedl) and in adult plant stage (EA-N-adult) of spring barley cultivars infected with Puccinia hordei.

\begin{tabular}{|c|c|c|c|c|}
\hline Character & MDS-1998 & MDS-1999 & RLP-seedl & EA-N-seedl \\
\hline MDS-1999 & $0.95 * *$ & - & & \\
\hline RLP-seedl & $-0.60 * * \S$ & $-0.58 * \S$ & - & \\
\hline EA-N-seedl & $-0.42 *$ & $-0.44^{*}$ & $0.79 * * \S$ & - \\
\hline EA-N-adult & $-0.50 * *$ & $-0.50 * *$ & $0.74 * * \S$ & $0.85 * *$ \\
\hline
\end{tabular}

* Correlation is significant at the 0.05 level (1-tailed), ** at the 0.01 level (1-tailed).

$\dagger$ Based on $n=27$, unless stated otherwise.

$\S$ Based on $n=15$, since only on accessions with high infection type the latency period could be determined.

may occur in those four accessions or in any of the other accessions.

\subsection{Virulence survey}

All or nearly all the 341 isolates carried virulence for the resistance genes $R p h 1, R p h 2, R p h 4$, $R p h 6, R p h 8, R p h 9$ and $R p h 12$ (Tab. II). For several genes (Rph3, Rph5, and the $R$-gene in Hor500-1) virulence occurred in moderate to high frequencies, about 20 to $90 \%$. Virulence to the resistance in Hor1132 sel. occurred in low frequencies.

$R p h 7$ is the only gene for which none of the isolates carried virulence.

The differences in virulence frequencies between the countries are quantitative, and only in a few cases substantial (Tab. II). For example, the virulence frequency for Quinn was higher in the UK (83\%) than in Germany (20\%). The results of surveys carried out in 1997 and 1999 were essentially the same (data not presented).

\subsection{Level of non-hypersensitive resistance}

The most important component of partial resistance, latency period, could only be determined on the 17 accessions that exhibited a compatible infection type (IT 7 or higher) to isolate 24
(Tab. III). The variation between the accessions for latency period of the leaf rust fungus was continuous. The extremes were L94 (the shortest latency period) and 'Ria' and 17-5-16 (latency period $144 \%$ of that on L94).

The second parameter used to quantify the level of partial resistance was the percentage of infection units that abort early, before having made a haustorium. This abortion is not associated with plant cell necrosis. Also in accessions with an effective $R p h$ gene, the level of early abortion without necrosis can be determined, since the Rph gene only will be effective on the infection units that succeed in producing at least one haustorium [9].

The percentage of early aborted infection units without plant cell necrosis (Tab. III) ranged from 2 ('Madeira') - 45 ('Ria') percent in the seedling stage, and from 2 (L94) - 56 ('Jacinta') in the adult plant stage. Early abortion of infection units in adult plants correlated closely with the early abortion of infection units in seedlings $(r=0.85$, significant at 0.01 level, Tab. IV). In most accessions, the level of early abortion was higher than in 'Grit'. Many accessions exhibited a higher level of early abortion than the partially resistant 'Vada'.

The level of early abortion and the relative latency period on the accessions were significantly correlated with the mean disease severity in 1998 and 1999 (Tab. IV). 


\section{Discussion}

The objective of the present study was to assess the level of resistance against $P$. hordei in modern West-European spring barley germplasm, and to determine the mechanism of the resistance. The barley set tested consisted of modern spring barley test lines and as references 'Grit' (partially resistant reference) and 'Alexis' (susceptible), and four research lines and cultivars that ranged from extremely susceptible (L94), through partially resistant (116-5 and 'Vada') and one line with an extreme level of partial resistance (17-5-16). The latter four lines featured in detailed studies on mechanism and genetics of partial resistance $[8$, 17, 19-22].

The evaluation of the barley set in field plots at different locations over two seasons (Fig. 1), and greenhouse data on race-specific resistance and partial resistance (Tab. III) provide a comprehensive impression of the level and type of resistance present in this germplasm.

It is obvious that the susceptible reference 'Alexis' is more susceptible than 'Grit' at almost every location. Apparently, the Rph 9 or Rph12, and $R p h 3$ genes that are presumably present in 'Alexis' (Tab. III) are of negligible effect. This is not surprising since virulence for $R p h 3, R p h 9$, and $R p h 12$ commonly occurs in West-Europe (Tab. II). Still, even 'Alexis' has some level of resistance, since it is less severely infected than L94 (Fig. 1). This may be ascribed to a low level of non-hypersensitive, partial, resistance, as manifested by a slightly higher rate of early abortion of infection units in 'Alexis' (Tab. III).

Many accessions were significantly more resistant than the moderately resistant reference 'Grit' (Tab. III). The type of resistance of 'Grit' is not clear from our data. 'Grit' is postulated to carry $R p h 12$, but this gene should not be effective against the $P$. hordei population present in the region (Tab. II). On seedlings of 'Grit', the leaf rust had a relative latency period of $124 \%$, which was comparable to the latency period on 'Vada' (Tab. III). This would suggest a rather high level of partial resistance in 'Grit'. However, the low percentage of early abortion of infection units on 'Grit' in seedlings and adult plants is similar to that in 'Alexis', and contradicts the conclusion that 'Grit' would have a fair level of partial resistance. A remaining possibility is that 'Grit' may have, in addition to the ineffective $R p h 12$, another $R p h$ gene that is only effective in the adult plant stage. Indeed, adult plants of 'Grit' showed a low infection type with isolate 24 in the greenhouse (data not presented). Such adult plant hypersensitivity resistance is commonly found in the wheat leaf rust $[23,30]$, but has not yet been described for barley leaf rust.

The results indicate that many accessions have a level of partial resistance that is as high or higher than that of 'Vada'. This is suggested by the high percentages of early abortion without necrosis observed in the seedling and in the adult plant stage. For those accessions that had a high infection type, the level of early abortion without necrosis was positively and significantly correlated with the relative latency period (Tab. IV). The negative and significant correlation between these two parameters for partial resistance and the observed infection levels in the field trials indicate that partial resistance substantially protects those accessions against the barley leaf rust fungus. An exception is 'Bartok', which was in the field trial not particularly resistant, but in the greenhouse appeared similar to 'Vada' in level of partial resistance.

It is interesting that several accessions ('Ria', 'Jacinta', and 'Cork') appear to have a similar level of partial resistance as line 17-5-16 (Tab. III). The latter line was produced from a selection programme in which genes for partial resistance from 'Vada' and 'Cebada Capa' were combined [19]. In the late 1970-s Parlevliet et al. [18] quantified the level of partial resistance in 40 West-European spring barley cultivars, by field assessment and measurement of latency period in seedlings and adult plants. In that study, the cultivars with the highest level of partial resistance, 'Lofa Abed' and 'Varunda', had a similar level of resistance as 'Vada'. The present data suggest that the breeders further increased the level of partial resistance in 
the spring barley germplasm. An accumulation of quantitative genes for partial resistance may easily occur, since there is evidence for abundance of loci that carry such genes [22]. Indeed, simply by repeated cycles of intercrossing barley genotypes and selecting against the highest levels of susceptibility, breeders can increase the level of partial resistance in their germplasm [17].

The present data suggest that most barley accessions carried at least one $R p h$ gene. Especially $R p h 3, R p h 12$ and/or $R p h 9$ were frequently postulated (Tab. III). Recently, Dreiseitl and Steffenson [3] postulated the Rph genes in Czech and Slovak barley cultivars. They also found that the large majority of cultivars carried one or two Rph genes, often $R p h 3+R p h 12$, but also $R p h 2$ was postulated frequently, for which there was no evidence in the present study. Both studies suggest that the large majority of cultivars possess $R p h$ gene(s) that are hardly or not effective, because the virulence survey (Tab. II) demonstrates that to all the known $R p h$ genes, except to $R p h 7$, virulence has developed in Europe. To some $R p h$-genes (Rph3, Rph5, and the $R$-gene in Hor500-1) virulence occurred in moderate frequencies. Also such genes will not be effective in protecting barley against the leaf rust, since selection of virulent pathogen genotypes should be expected to occur if cultivars with such resistance genes are sown over large areas. For this reason, also the resistance in Hor1132 sel is hardly of any use. Virulence is present already in the $P$. hordei population, although in low frequencies.

Several accessions contain hitherto unknown genes for hypersensitivity resistance. The most resistant accession was Hadm. 18091-96, in which the early abortion without necrosis was relatively low. Since Hadm. 18091-96 had a low infection type to all differentiating leaf rust isolates, the high resistance in this accession may be due to $R p h 7$ or other Rph-gene(s) to which virulence in the pathogen is rare or absent. Also the resistance in 'Hanka' may be due to $R p h 7$ rather than to partial resistance. Virulence for $R p h 7$ appears to be absent in Europe at present (Tab. II). In the USA, however, this resistance is not effective anymore, as virulence developed in the local $P$. hordei population [26]. Since $R p h 7$ results in complete resistance to avirulent races, it is surprising that 'Hanka' is infected to some extent in the field trials. Several explanations are possible. It may be that in the genetic background of 'Hanka' the expression of $R p h 7$ is incomplete. Niks and Kuiper [8] studied the expression of $R p h 7$ that had been introduced from Cebada Capa into L94, 'Zephyr' and 'Vada' by repeated backcrossing. In those backgrounds the $R p h 7$ was expressed more weakly (i.e. some reproduction by the fungus) than in 'Cebada Capa'. Another explanation could be that under certain environmental conditions the expression of $R p h 7$ is incomplete.

It may be expected that the differences in amount of infection between the accessions as measured in the field trials in this study would be much larger if the accessions would have been grown in isolated plots or on commercial fields. In our study, the accessions were grown in small adjacent plots. Parlevliet and van Ommeren [16] demonstrated that in such trials interplot-interference plays an important role. This, however, will not affect the ranking of accessions.

A matter of concern to breeders is the stability of the resistance over locations and years. Important cultivar $\times$ year or cultivar $\times$ location interactions in level of resistance may be due to race specificity of the resistance, presuming that race composition of the pathogen varies in time and place. Another factor would be environmental effects on the expression of the resistance itself. A well known example is the temperature sensitivity of several resistances, for example $R p h 7$ that has been reported to be ineffective at about $5{ }^{\circ} \mathrm{C}$ [1]. Our data indicate that in some accessions the level of resistance depended on year or location. The relative instability of the resistance of Hadm.3500-96 may be caused by race-specificity. This accession was resistant to all differentiating isolates in Aschersleben, but susceptible to isolate 24 (Tab. III). This indicates the presence of one or more $R p h$-genes that are effective to most isolates, but to which virulence may occur locally.

It is remarkable that 'Cork' and 'Ria' are among the less consistently performing accessions. These two cultivars appeared to have a very high level of 
partial resistance (Tab. III). Parlevliet and van Ommeren [16] found that partial resistance may show large variation in magnitude between experiments, e.g. because of differences in experimental design, but in general the ranking between accessions remains essentially the same. Interestingly, they reported an exception in 'Goldmarker', that differed in ranking between the UK and Wageningen. This difference was "not easy to explain" according to these authors. Partial resistance of barley to leaf rust is not considered to be highly dependent on environment [11]. Moreover, it is not generally considered race-specific, although minor race-specific effects have been observed $[12,21]$. The extreme partially resistant line, 17-5-16, however, consistently ranked among the most resistant accessions, indicating a stability of partial resistance.

Another prominent case of unstable performance was 'Grit', the moderately partially resistant reference cultivar, that had such an excellent stability before [29]. At Hadmersleben, where the general infection level was highest of all locations (Fig. 1), the resistance in 'grit' was poorly expressed. One possible explanation could be that under high infection pressure, the resistance of this accession, and maybe some of the other accessions, is not completely effective. This would agree with the finding by $\varnothing_{\text {stergård, Damgaard and Tomiuk }}$ (unpublished data) that ranking of cultivars with respect to two components of partial resistance against powdery mildew depended on inoculum density [27].

In summary, we conclude that the high general level of resistance in the present set of WestEuropean modern spring barley accessions can mainly be ascribed to high levels of partial resistance. It appears that major $R p h$-genes contribute to the resistance in only a few accessions.

Acknowledgements: The authors acknowledge the support by the COST Action 817, which enabled the extensive network of cereal workers to meet and exchange ideas and material. We are very grateful for the inspiring and effective leadership by Chairperson Hanne Østergård in this Action.

We thank F.G. Felsenstein for providing most isolates for the virulence survey.

\section{Appendix}

Ole ANDERSEN: Sejet, Planteforaedling, Nørremarksvej 67, Sejet, 8700 Horsens, Denmark

Kerstin Flath: Fed. Biol. Res. Centre for Agric. and Forestry, Außenstelle Kleinmachnow, Stahndorfer Damm 81, 14532 Kleinmachnow, Germany

Paul GyMER: Agrifusion Ltd, Agricultural Research Station, Maldon Road, Woodham Mortimer, Maldon, Essex, CM9 6SN, UK

Fritz HeINRICHS: Saatzucht Hadmersleben GmbH, Kroppenstedler Straße, 39398 Hadmersleben, Germany

Rickard JonsSON: Svalöv Weibull AB, 26881 Svalöv, Sweden

Lissy KunTzE, Edeltraut RICHTER: Nordsaat Saatzuchtgesellschaft, Hauptstraße 1, 38895 Böhnshausen, Germany

Morten RASMUSSEN: Abedfonden Abed Plant Breeding Station, Abedvej 39, 4920 Søllested, Denmark

\section{References}

[1] Clifford B.C., Barley leaf rust, in: Roelfs A.P., Bushnell W.R. (Eds.), The Cereal Rusts, Vol. II. Diseases, distribution, epidemiology, and control, Acad. Press, Orlando, 1985, pp. 173-205.

[2] Cotterill P.J., Park R.F., Rees R.G., Pathogenic specialization of Puccinia hordei Otth in Australia, 1966-1990, Aust. J. Agric. Res. 46 (1995) 127-134.

[3] Dreiseitl A., Steffenson B.J., Postulation of leafrust resistance genes in Czech and Slovak barley cultivars and breeding lines, Plant Breed. 119 (2000) 211-214.

[4] Griffey C.A., Das M.K., Baldwin R.E., Waldemaier C.M., Yield losses in winterbarley resulting from a new race of Puccinia hordei in North America, Plant Dis. 78 (1994) 2256-2260.

[5] Jin Y., Steffenson B.J., Inheritance of resistance to Puccinia hordei in cultivated and wild barley, J. Hered. 85 (1994) 451-454.

[6] McNeal F.H., Konzak C.F., Smith E.P., Tate W.S., Russell T.S., A uniform system for recording and processing cereal research data, USDA, Agricultural Research Service, Washington D.C., ARS 34-121, 1971, pp. $1-42$. 
[7] Moll E., Walther U., Flath K., Prochnow J., Sachs E., Methodische Anleitung zur Bewertung der partiellen Resistenz und die SAS-Anwendung RESI, Berichte aus der Biologischen Bundesanstalt für Land und Forstwirtschaft 12 (1996).

[8] Niks R.E., Early abortion of colonies of leaf rust, Puccinia hordei, in partially resistant barley seedlings, Can. J. Bot. 60 (1982) 714-723.

[9] Niks R.E., Kuiper H.J., Histology of the relation between minor and major genes for resistance of barley to leaf rust, Phytopathology 73 (1983) 55-59.

[10] Niks R.E., Rubiales D., Avirulence factors corresponding to barley genes $\mathrm{Pa} 3$ and $\mathrm{Pa} 7$ which confer resistance against Puccinia hordei in rust fungi other than P. hordei, Physiol. Mol. Plant Pathol. 45 (1994) 321-331.

[11] Parlevliet J.E., Partial resistance of barley to leaf rust, Puccinia hordei. I. Effect of cultivar and development stage on latent period, Euphytica 24 (1975) 21-27.

[12] Parlevliet J.E., Evidence of differential interaction in the polygenic Hordeum vulgare - Puccinia hordei relation during epidemic development, Phytopathology 67 (1977) 776-778.

[13] Parlevliet J.E., Further evidence of polygenic inheritance of partial resistance in barley to leaf rust, Euphytica 27 (1978) 369-379.

[14] Parlevliet J.E., Strategies for the utilization of partial resistance for the control of cereal rusts, in: Simmonds N.W., Rajaram S. (Eds.), Breeding strategies for resistance to the rusts of wheat, CIMMYT, 1988, pp. $48-62$.

[15] Parlevliet J.E., Selecting components of partial resistance, in: Stalker H.T., Murphy J.P. (Eds.), Plant Breeding in the 1990s, CAB International, Wallingford, UK, 1992, pp. 281-302.

[16] Parlevliet J.E., van Ommeren A., Interplot interference and the assessment of barley cultivars for partial resistance to leaf rust, Puccinia hordei, Euphytica 33 (1984) 685-697.

[17] Parlevliet J.E., van Ommeren A., Accumulation of partial resistance in barley to barley leaf rust and powdery mildew through recurrent selection against susceptibility, Euphytica 37 (1988) 261-274.

[18] Parlevliet J.E., Lindhout W.H., van Ommeren A., Kuiper H.J., Level of partial resistane to leaf rust, Puccinia hordei, in West-European barley and how to select for it, Euphytica 29 (1980) 1-8.
[19] Parlevliet J.E., Leijn M., van Ommeren A., Accumulating polygenes for partial resistance in barley to barley leaf rust, Puccinia hordei. II. Field evaluation, Euphytica 34 (1985) 15-20.

[20] Qi X., Niks R.E., Stam P., Lindhout P., Identification of QTLs for partial resistance to leaf rust (Puccinia hordei) in barley, Theor. Appl. Genet. 96 (1998) 1205-1215.

[21] Qi X., Jiang G., Chen W., Niks R.E., Stam P., Lindhout P., Isolate-specific QTLs for partial resistance to Puccinia hordei in barley, Theor. Appl. Genet. 99 (1999) 877-884.

[22] Qi X., Fufa F., Niks R.E., Lindhout P., Stam P., The evidence for abundance of QTLs for partial resistance to Puccinia hordei on the barley genome, Mol. Breed. 6 (2000) 1-9.

[23] Roelfs A.P., Resistance to leaf and stem rusts in wheat, in: Simmonds N.W., Rajaram S. (Eds.), Breeding strategies for resistance to the rusts of wheat, CIMMYT, 1988, pp. 10-22.

[24] Rohringer R., Kim W.K., Samborski D.J., Howes N.K., Calcofluor: an optical brightener for fluorescence microscopy of fungal plant parasites in leaves, Phytopathology 67 (1977) 808-810.

[25] Schwarzbach E., A high throughput jet trap for collecting mildew spores on living leaves, Phytopathol. Z. 94 (1979) 165-171.

[26] Steffenson B.J., Jin Y., Griffey C.A., Pathotypes of Puccinia hordei with virulence for barley leaf rust resistance gene $R p h 7$ in the United States, Plant Dis. 77 (1993) 867-869.

[27] de Vallavieille-Pope C., Giosue S., Munk L., Newton A.C., Niks R.E., Østergård H., PonsKühnemann J., Rossi V., Sache I., Assessment of epidemiological parameters and their use in epidemiological and forecasting models of cereal airborne diseases, Agronomie 20 (2000) 715-727.

[28] Walther U., Development of pathogen populations of Puccinia hordei Otth in Germany (1974-1994) and in the neighbouring countries (since 1992) under consideration of biotic and abiotic influences, in: Limpert E., Finkh M.R., Wolfe M.S. (Eds.), COST 817, Proc. Integrated Control of cereal mildew and rusts: towards coordination of research across Europe. ISBN 92-827-7171-7; European Commission,ECSC-ECEAEC, Brussels, 1996, pp. 119-124. 
[29] Walther U., Prochnow J., Entwicklung und Möglichkeiten der Züchtung auf 'dauerhafte Resistenz', dargestellt an Ergebnissen langjähriger Sortenprüfungen bei der Wirt/Pathogenkombination Gerste/Zwergrost, Bericht über die 46. Arbeitstagung 1995 der "Arbeitsgemeinschaft der Saatzuchtleiter" in Gumpenstein, 1995, pp. 181-188.

[30] Winzeler M., Mesterházy A., Park R.F., Bartos P., Csösz M., Goyeau H., Ittu M., Jones E.,
Löschenberger F., Manninger K., Pasquini M., Richter K., Rubiales D., Schachermayr G., Strzembicka A., Trottet M., Unger O., Vida G., Walther, U., Resistance of European winter wheat germplasm to leaf rust, Agronomie 20 (2000) 783-792.

[31] Zadoks J.C., Chang T., Konzak C., A decimal code for the growth stages of cereals, Weed Res. 14 (1974) 415-421.

To access this journal online: www.edpsciences.org 